\title{
KNITTING HARMONY IN DIVERSITY: \\ A BEST PRACTICE FOR RELIGIOUS HARMONY IN THE PASALAE COMMUNITY-NORTH GORONTALO
}

\author{
Nensia \\ Balai Penelitian dan Pengembangan Agama Makassar \\ Jl. AP. Pettarani 72 Makassar \\ Email:nensia.s@gmail.com \\ St. Aflahah \\ Balai Penelitian dan Pengembangan Agama Makassar \\ Jl. AP. Pettarani 72 Makassar \\ Email: sitti.aflahah@gmail.com \\ Sitti Arafah \\ Balai Penelitian dan Pengembangan Agama Makassar \\ Jl. AP. Pettarani 72 Makassar \\ Email: sittiarafah0702@gmail.com
}

Article received July $9^{\text {th }}, 2021$; Article revised September $28^{\text {th }}, 2021$; Article approved October $22^{\text {th }}, 2021$

\begin{abstract}
This research aims to describe the best practice of religious harmony in the Pasalae community, North Gorontalo. As a qualitative research, data collection techniques were used through direct observation of the Pasalae community activities in building relationships and practices of harmony which has been going on all this time. Interviews were intended to explore data from the key and regular informants as deep as possible, and documents aim to obtain data through articles related to best practices in Pasalae. The study results show that the people in Pasalae Village live in an excellent practice of religious harmony. The Muslim and Christian communities, living side by side peacefully and actively build relationships without being awkward. The basis of harmony in the Pasalae community is created through culture and local wisdom that is still rooted in society, economy, and kinship. The presence of religious groups considered fanatic is one of the threats in breaking up their harmony. Thus, the effort to prevent it is by increasing the awareness among the people of Pasalae so that they are not easily provoked, and building an intense dialogue on any problems that arise in the community.
\end{abstract}

Keywords: best practice, religious harmony, pasalae community

\section{INTRODUCTION}

$\mathrm{I}$ nter-religious harmony in Indonesia is crucial since people should deal with diverse religions, ethnicities, and races. The face of a pluralistic in Indonesia is highly determined by the harmony in a society. This condition is in line with Walzer's statement, Diversity makes harmony (tolerance) important, and through harmony, diversity is possible (Walzer, 1997).

The United Nations Support Facility for Indonesian Recovery (UNSFIR), has released data regarding conflicts between religious communities in Indonesia. After the reformation, from 1988 to 2003, conflicts involving inter-religious communities were 428 cases. Most cases occurred in 1998 to 2000 , in the first three years of reformation, which were 297 cases. Meanwhile, according to the findings of the SETARA Institute, there were 265 cases of violence and intolerance in 2008 (Hasani, 2008, viii).

Social scientists say that religion is one of the causes of conflict or violence. Islam and Christianity are major religions in the world, both encourage their adherents to spread their religious mission. Therefore, it must be managed properly and correctly to not lead to the emergence of a conflict or violence. "Religious Revival", practically occurs in religions globally so that adherents seek a way 
out. This situation can lead to the violence if the religious expressions are not implemented properly and correctly (Ali Fauzi, n.d., 29-30). Recently, the issue of social conflict is suspected to have colored religious social life at the local, national, and international scale. It describes situations that threaten the harmony of community life. However, the community in North Gorontalo including in Pasalae does not experience such situation and condition. A portrait of a peaceful life and harmony is still found there, which is built through strengthening social, economic, and cultural relations.

In the trajectory of history, North Gorontalo is an area where the people live in a harmonious frame. This situation illustrates Islam as the majority but does not ignore other religions as the minority. Both of them live side by side from various ethnicities, tribes, races, and religions. Gorontalo has the philosophy "Religion is based on syara' and syara' is based on the Kitabullah", as a way of life for the people in Gorontalo, including the people in the Pasalae.

In addition, this area was once part of North Sulawesi where people's lives were also colored by Sangir and Minahasa cultures. However, the community can build the dynamic relationships among different ethnicities, races, or religions. They live side by side in an atmosphere of peace and harmony, taking care of each other, and respecting each other with the principle of "Torang Samua Basudara" (we all brothers). Pasalae, for example, is one of the villages at the end of North Gorontalo, which borders Bolaang Mangondow.

The practice of tolerance built between them naturally is still found. Harmony is created by itself and has been a tradition to this day. The Pasalae people practice active, sincere, and uncompromising religious tolerance between the two communities. Therefore, this study will photograph the practice of religious harmony in the Pasalae community by raising the following research questions: 1) What is the description of the community in Pasalae Village who can live together peacefully with several ethnicities, tribes, and religions? 2) What is the description of the people of Pasalae Village in building active relationships in various aspects of life? And 3) How do the people of Pasalae Village maintain and deal with the influence of religious extremism from outside groups? The aims of this research are: 1) To describe the life picture of the community in Pasalae Village who can live together peacefully with several ethnicities, tribes, and religions. 2) To find out the description of the people of Pasalae Village in building active relationships in various aspects of life and 3) To find out how the community protects their religious harmony from outside influences, especially groups that are considered extreme.

\section{Theoretical Perspective}

\section{Best Practice}

"Best experience" is a benchmark to describe a Best Practice, both in the community and in groups, especially in carrying out a task. The success of a best practice is if it can develop a new model or idea that is more innovative and can lead to a change. Also, its impact is sustainable.

Based on the intent of the best practice above, if it is associated with the religious harmony, it is expected that in different communities, there will be "best experiences" or best practices as an effort to build harmony in life and have a sustainable impact. Moreover, these best practices are expected to become a developing new idea or model and can be used as a model to overcome conflict in a plural society.

\section{Active Tolerance: Diversity Greeting Each Another}

How can tolerance actually be built? According to the history of religious tolerance, in Walzer's view (1997), tolerance should start from the millet system. The millet system, in Walzer's view, is simply the recognition of different religions as a group where individuals are only recognized for their existence because they socialize with that group. Thus, the Millet system makes it possible to tolerate the actions or authorities of other religious groups (in this case Christianity).

Religious tolerance in the millet model is still looming even though the state has taken the form of a nation state and is no longer a model of a royal state, such as in the style of the Ottoman dynasty or the Majapahit kingdom. This model is the same as the tolerance model in Indonesia. In addition to the millet model, active tolerance is also 
described by Walzer, especially in the last three dimensions. He calls it the tolerance regime, namely: 1) accepting and acknowledging the others' rights, 2) not only showing recognition but also openness to others or at least the curiosity to understand the other better. And 3) support, care for, and celebrate differences. It could be because diversity is sunnatullah, also because diversity is a land for sowing better human development (Syamsurijal, 2019: 4).

According to Diana L. Eck (2006), tolerance is actually not enough to only build a truly harmonious religious life. Tolerance is simply generosity to accept different. In such a situation, it is still felt that there is a more dominant group. Then Diana L. Eck proposed another concept which she called pluralism. Pluralism is not only limited to tolerance but also an enthusiastic attitude and active behavior in experiencing an encounter in the midst of diversity (Diana, 2006).

\section{RESEARCH METHOD}

Qualitative-Ethnographic, is the method that was used in this research by describing the data systematically, factually and accurately. It is called ethnographic because it describes in detail the practice of harmony in society, including describing the culture and local wisdom that supports the harmony (Spradley, 2007:12).

Observation, interview, and document study as data collection techniques were used in order to obtain data in the field. The researchers observed directly the various people's daily activities as the best practices of religious relations. Interviews were conducted with a number of informants who were considered to know the issues to be explored including traditional leaders, religious leaders, community leaders, village governments, and other communities (Kasniyah, 2012: 36) Document studies were conducting data through documents related to research topic, including village monograph data and several articles related to the best practiced. Furthermore, the collected data was described, studied in detail, reduced, and analyzed using qualitative descriptive analysis (Endraswara, 2006: 176).

\section{DISCUSSION}

\section{Photographing the Social and Religious Life of the Pasalae Community}

Pasalae Village, is a coastal area in the northern part of the Gentuma Raya subdistrict, consisting of four hamlets, inhabited by various ethnicities and tribes, such as Attingola, Kaidipang Bolaang Mangondow, and Gorontalo are considered to be indigenous. The others are Sangir and Minahasa who are immigrants. The presence of other tribes as immigrants such as Arabs. It is indicated by the discovery of various clans, including; Alidrus, Alamri, Alhamid, Almahsyur, Al Anoez which spread to several villages, including in Pasalae. Likewise, the Bugis tribe, as fishermen who move around, even intermarried with the Gorontalo tribe and finally settled in Pasalae.

The Sangir and Minahasa tribes arrived on a large scale in Gent uma, as told by Pastor Setyo. The presence of the two tribes, especially Sangir, is a result of the natural disaster when Karangetan Mount erupted in Marisa. It spread them to the coast and highlands so that colonization occurred in the 1940s. They came and scattered in several villages, including in Pasalae and lived as farmers. Along with that, agricultural extension workers are needed who are expected to provide counselling to farmers to grow crops well. The instructors came from the Minahasa tribe and eventually settled in Gent uma. It was the beginning of the presence of the Minahasa tribe in Gentuma, including in Pasalae.

Administratively, Pasalae Village became the definitive village in 2010. At the beginning of its formation, there were two officials, Mrs. Serni Panu (2010-2011) and Mr. Amran Kambayang (2011- July 2012). After village elections were held in early 2012, then precisely in July 2012, Hamzah R Tatu was elected and became the first Definitive village head for the period June 2012 to March 2018. After that, it was held by Ismail Polapa, SE, from March to December 11, 2018. Then simultaneous village head elections were held throughout the Gent uma Raya sub-district, in December 2018. As a result, Ramdan Mapaliey was elected as the Definitive Village head for the 2019-2024 period. The demographic condition of Pasalae Village is divided into 2 major religious groups, Islam 
and Christianity. The Muslim population is 1012 people $(70 \%)$ and Christian is 411 people $(30 \%)$. Islam as the majority in various activities is still thick with customs or traditions in various cycles of life and death (Tim Penyusun Dokumen Desa, 2018: 1-4).

Besides Islam, in Gorontalo, the entry of Christianity was closely related to the competition for territorial expansion between the Port uguese and the Sultanate of Ternate. In 1563, Sultan Hairun intended to dominate North Sulawesi, but was preceded by the Port uguese. Then, troops were sent with two kora-kora ships that brought Peter Magehheas to Manado, a small island in Manado, namely Minahasa. The King of Manado and his 1500 people were baptized. Two weeks later Peter's ship sailed to Kaidipang on the North Coast of Gorontalo, where he baptized 2000 people. In Kaidipang for 8 days, Peter taught Christianity to the people. The next five days, another missionary baptized King Sangir and his people. In a subsequent development, when the Verenigde Oast Indische Compagnie came to power in Gorontalo, in 1705 Christians were already present in the Gorontalo region, namely Attingola, from where Christianity began to spread its wings. This development eventually led to the fact that many teachers of the Christian congregation in 1926 were sent to Gorontalo. The development of Christianity in Gorontalo is not as fast as other regions, this is because Islam has long developed as the official religion of the kingdom(Apriyanto, 2012:813).

Referring to its history, Islam is the first religion developed and embraced by the people in Pasalae. Christianity was also present along with the entry of the Sangir and Minahasa tribes. However, until now both of them are hand in hand and the people of Pasalae call it "baku masuk". Both run based on rules or norms based on the Al-Qur' an and the Bible. The relationship between Islam and Christianity in the village of Pasalae is going harmonious. For reasons of harmony, it can clearly be seen from how the values of these two religions are implemented in social and religious relations.

A mat ure awareness in religion makes these two religions can unite. Religion is practiced according to the norms taught in each religion. The relationships that are built run on religious ways, without ignoring human values. The result of the observations on the Muslim and Christian communities in Pasalae, for example in relationship to the creator are not neglected, carrying out religious routines without disturbing each other, both communities carry out it meaningfully.

The Muslim community for example, when it comes to prayer time, they do not neglect to go to the mosque. For Christians, they also carry out worship activities, they worship in churches and at home (services) through chanting songs and prayers without disturbing each other. Similarly, on Fridays and Sundays, both of them do not feel awkward to remind each other.

The religious relations that have developed between them are almost seamless. However, some believe that religious relations are currently experiencing a slight shift in the religious context. It is shown by the presence of more fanatical religious attitudes and behavior, particularly since the presence of the jama'ah tablig. Such attitudes and actions are the implementation of religious days, for example giving Christmas greetings. In the religious practice of the Muslim community which is still thick with customs and traditions, Muslims should not give Christmas greetings because there is no basis or it was not carried out at the time of the Messenger of Allah. It is marked by the presence of more fanatical religious attitudes and behavior. Nevertheless, in the context of humanity they remain intimately entwined.

\section{Religious Harmony: A Best Practice for Pasalae Community Harmony}

Tri Religious Harmony is proclaimed by the government and quoted by Yewanggoe (2016) so as not to be trapped in unnecessary conflicts. As a plural country, Indonesia has declared Tri Harmonies which are Harmony between Religious People, Inter-Religious Harmony, and Inter-Religious Harmony with the Government. It is not a theological formulation, but a formula that regulates people of different religions so that they do not get into conflict (Yewangoe, 2016:28).

In order to strengthen tolerance and inter-religious harmony, Mukti Ali as the Minister of Religion initiated the need to apply the principle of agree in disagreement in inter-religious relations. This approach requires each religious adherent to respect and 
appreciate followers of other religions. Mukti Ali rejects tolerance and harmony which is built on the basis of syncretism, preconceptual synthesis, and religious replacement (Ismail, 2017:30). Maftuh Basuni asserts that Religious Harmony is a dynamic pillar of national harmony, so it needs to be maintained, always based on the value of tolerance, respect for differences, including the practice of religious values in society and in the state (Nazmudin, 2017:24).

\section{a. Trust and Respect Each Other in Differences}

Islam and Christianity are recognized as religions that believe the same understanding that ethics and spirituality can only be lived by the adherents (from within), not from an outsider's point of view (from without). At that point, they understand and trust each other in their respective life experiences. Sociologically, they form their perspective on each other, so that they can trust each other (Mamuaya, et.al, 2017:9). Similarly, explains that mutual respect is the main key in building togetherness. (Akhyar, et.al , 2015:732).

Exploring the social relations of the people in Pasalae can represent a plural society in terms of ethnicity and religion. Mutual trust and mutual respect are the main assets of the Pasalae community in building a harmonious life. Therefore, they are willing to cooperate, help, and work together.

Pastor Marbon from Medan, told his experience,

As long as I served as a servant of the people at the Pentecostal church in Pasalae for approximately 21 years, I sometimes wonder in my daily life, greeting each other is normal, male or female, they even greet me first. I usually get confused, who is it... he joked. Between us there is no mutual suspicion, neighbors greet each other. Even if I go to the beach, I will definitely get fish. If I do not go to the dock, fishes are delivered to my home. Especially if there is a celebration of inviting each other and visiting each other or mourning without being invited by us or those present, and it's also common in the car for example when they see me, they greet me even though I don't know who he is. That is how we are here every day, very familiar and greet each other.

\section{b. Coexistence and Mutual Sharing}

In essence, religion contains universal values, which become norms or rules, including in terms of relations between people. Likewise, the case of community practices in the two communities in Pasalae. Islam as the majority made the minority a part of their life and not the liyan. On the other hand, Christians as a minority made Islam the protector, thus successfully created balanced in social relations between the two communities in their daily lives. This made them willing to live together in a big community.

Pluralism as a reality cannot be separated from the context of human life. A human being must realize himself, that a man does not live with himself only, but a man needs other people as a partner, in sharing, discussion and in process. In other words, every individual need other people to coexist in order to live together based on respect to each other in differences. (Tiwery, 2018: 8).

The community of Pasalae has lived peacefully for generations. Greeting each other, respecting, sharing, and helping each other were things that become real in their daily practice. The two communities built active relationships, which unite without any awkwardness.

Raden Kumba, a traditional leader, recounts his experience of living with people of different religions, following the interview excerpts:

Kalau torang disini, kerukunan umat beragama so baik, tapi saya merasa deng Kristen sangat bagus. Di samping rumah saya ini kritstiani, sebelah menyebelah. Tapi kita menganggap satu kandungan satu bapak satu mama, tidak ada yang saling baku kasar. Baginya, tetangga merupakan saudara yang paling terdekat sehingga mo boleh cekcok, saling batagur sapa, mo ba antar makanan itu so biasa, kalau dorang ada acara kawinan mo pake adat saya mo datang, itu yang terjadi disini sehingga sampai hari ini mo bilang nyanda ada mo ba konflikkonflik, aman dang, yang penting so mo baku sayang, menghargai walaupun kita beda agama karena kita berasal dari dari adam dan hawa. Pengalaman yang pernah menderah dan sulit saya lupakan ketika saya mengalami sakit selama 3 bulan, merekalah yang membuatkan bubur, memberikan beras, atau meminjamkan uang, tidak sama dengan teman-teman dari muslim yang masih pikir-pikir, apalagi jika diberikan secara cuma-cuma. (wawancara, Raden Kumba, 13 Maret 2019, di Pasalae). 
(For the people, religious harmony is already well maintained, I personally feel the Christians are kind. Next to my house is a Christian. But we consider that we came from one womb, one father, one mother, and there is no harsh standard against each other. The neighbors are the closest relatives, so you can argue, greet each other, give food, and those are normal. If they hold a wedding party in their custom, I would be delighted to come, that is what happened here, no conflicts, the situation is safe. The important thing is loving and respecting each other even though we have different religions because we come from Adam and Hawa. An experience that was painful and difficult for me to forget when I was sick for 3 months, they were the ones who made porridge, gave rice, or lent money, which for other Muslim neighbors would think twice, especially if giving things for free. (Interview, Raden Kumba, 13 March 2019 in Pasalae).

A life in greeting and mingling that kept on maintained. That is the portray of the people in Pasalae that makes them close. The interaction between them was without awkwardness, in their terms called as baku masuk, or accepting each other, there was no obstacle or reason for them not to interact.

Real portraits, best practice in Pasalae Village, namely through the building their houses which side by side without distance, even Christian houses were at the crossroad of the mosque, and also Muslim houses were side by side with the church. This condition made them interact intensely, share, and give each other which in their terms is called lewat dapur which means a neighbor is not a foreigner, basudara is almost boundless, this had become a tradition in the life of the Pasalae community.

\section{c. Family Events and Religious Day Celebrations}

Besides living as close neighbors, the Muslim-Christian community in Pasalae, in various life cycles interacted openly, for example in a haircut ceremony or aqiqah, weddings, mourning even on religious celebration days. The practices shown by the two communities seem to cross religious boundaries. Why did this happen? Apparently, this was due to the existence of strong social relations and kinship.

Attitudes and acts of inviting each other, visiting each other became a practice found in the life of the people of Pasalae. In particular, for example, in a Christian wedding ceremony, the Muslims especially the women, were directly involved in preparing the fete that will be served at the party.

In addition to the wedding party, best practice is also found in death or grief assembly whether in Muslim or Christian communities. Especially in the Christian funeral, the Muslims would help and prepare all the necessities from the beginning to the burial process. Moreover, in the series of mourning nights for Muslims, such as on the 40th day, by holding a commemoration.

In the grieving commemoration, they also invited the Muslim community. Even those directly involved in preparing the needs of fete (food) were prepared by Muslim women. Even the used utensils were Muslim's.

Other than celebrations held by the family, they also celebrated holy days to became closer to each other. Celebration of holy days was benefited to visit each other and exchange things. Likewise, when the celebration of Eid al-Fitr arrived, not a few of the Christians also rejoice and distribute pastries, even some of them provided basic needs to Muslim brothers.

On the other hand, if there were religious celebrations in Christians, such as Easter or Christmas, the Muslim community would also enliven it, for example in sports competitions. When Christmas celebrations arrived, they visited each other and even Muslim families helped them prepare Christmas feast, especially for families who have Muslim relatives. Likewise, those who did not have Muslim relatives, they asked their Muslim neighbors to help in prepare the Christmas feast. Besides that, Muslim brothers also distributed gifts in the form of pastries or drinks to Christians.

\section{d. The Traditional Market, Pier and Fish- Sharing Tradition}

Emile Durkheim, in the writings of (Waluyajati, et.al,2018: 85), claims that religion is a social thing. He also concluded that the primary purpose of religion in society is not to God but to each other. This is intended as an effort to achieve a social process or commonly called interaction. (Khotimah, 2016: 44). Social interaction is a relationship between two individuals, which is a relationship between two other individuals or vice versa, resulting in a social process. 
Traditional markets and piers as media or spaces were considered to strengthen religious harmony in Pasalae. As a meeting room in building social cohesion, traditional markets from various ethnicities, tribes, and religions meet. It was a place where interactions were established without awkwardness, mingled with each other, and cooperated in the economy. Not a few of the market participants came from the Pasalae community as sellers and buyers. People who came from Pasalae, both Muslim and Christian, peddled a variety of merchandise, their stalls were side by side, especially those who came from Pasalae.

In addition to the traditional market, the pier was also the most strategic meeting place to build intense communication for the people of Pasalae. Starting from sunrise to sunset, it has never been emptied from the activities of the people, especially the fishermen. When visiting the pier, dynamic relationships between people were easy to find from various ethnicities, religions, ages, gender, punggawa jeko (ship owners), crew members, and fish retailers called tibo-tibo and the others mingled and interacted kindly. Especially for the fishing community, when they return from fishing, they did not waste time gathering and sharing their sailing experiences. A cup of coffee, dominoes and chess were a companion that made them closer, blending in without barriers of ethnicity or religion.

Another exciting aspect is known as the tradition of bagi-bagi ikan. This is a tradition hold by their ancestors from generation to generation. Thus, it is good that this became the model or best practice, especially for the fisherman communities in common. This tradition can be found every day at the pier, when the fishing boats have anchored at the pier then unloading the catch, then there will be a crowd of people waiting for the shipowner or crew to give their share of fish. If the catch is abundant, then the punggawa jeko (shipowner) also give fish to the people in large amount, even for those who are at the pier at any time waiting for every boat would even get more fish. The fish they got was for side dishes at home, but some were sold to retailers or tibo-tibo. On the other hand, if the catch is only a few, the people would still get some fish but adjusted accordingly. In other words, every person or community who stops at the pier when the fishing boat rests would undoubtedly get some fish to bring back home.

Sharing catches with people is a long-standing tradition and is considered a social bond among people regardless of ethnicity, tribe, or religion. The hope is that the fish given to the people will be a blessing as a fortune obtained and bring good luck to the business. For the punggawa jeko or ship owners, it has become a principle that in every fort une earned, there is also another person's fortune in it, so it is necessary to give zakat to anyone who comes to the pier.

\section{e. Religious Conversion and Intermarriage}

Converting religion and marriage are two things that we often find in a pluralistic society in Indonesia. In the context of the community in Pasalae, these two things are considered standard and frequent problems, but so far this has not led to the impact of disunity or conflict between the two things.

The conversion of religion in this case, whether as convert or apostate, was handled wisely by the people of Pasalae. Religious conversion is caused mainly by marriage and social motives. Interaction, in this case, is the friendship between Islam and Christianity, especially teenagers/adults, which in turn generates interest in changing religions. As a result, it was not uncommon for them (Christians) to convert to Islam. On the other hand, it was undeniable that some Muslims have converted their religion because of intermarriage cases.

The phenomenon of intermarriage that occurs in the Pasalae community runs according to the provisions of the Marriage Law. Several cases of marriages that occurred in the 2010-2018 period were carried out after both parties chose one of the beliefs/religions, whether Islam or Christianity, which started with the process of religious conversion (convert or apostate), which was marked by a statement made by each individual who will convert, and made a letter of approval from the family. Likewise, if a Christian is about to convert to Islam, there will automatically be approval from the church and being expelled as a member of the congregation.

Regarding intermarriage in the Pasalae community, there were no cases of inter-religious marriage, but a person has to choose one belief. There is no prohibition for 
them in the intermarriage process, as long as they do not play with their beliefs, so that both parties must believe in the decisions they take first.

Concerning the issue of intermarriage, the following is an interview with priestess Rineke Mapaliey:

Kawin mawin yang terjadi, secara khusus dipihak Kristen, sudah ada beberapa jemaat yang memilih untuk pindah agama, lalu menikah, tapi kami tidak keberatan, tetapi jangan sampai mempermainkan keyakinan, sehingga di kami itu harus membuat pernyataan dari pribadi maupun keluarga, lalu diketahui oleh pihak gereja. Demikian pula sebaliknya jika dari pihak muslim yang masuk ke Kristen harus ada pernyataan yang ditandatangani oleh bersangkutan sebagai bukti bahwa mereka pindah agama, sehingga diharapkan nantinya tidak terjadi penyesalan yang akan membawa pada konflik. Memang di awal tentu ada persoalan, ya tapi itu hanya di dalam keluarga, tetapi lama kelamaan perseteruan itu berakhir, karena mereka menyadari bahwa keyakinan itu tidak bisa dipaksakan" (Wawancara Pendeta Rineke Mappalie, 16 Maret 2019 di Pasalae).

(The intermarriage that occurred, specifically on the Christian side, there were already some congregations who chose to change their religion and then get married, but we don't mind, but don't play with beliefs, so we have to make a statement from personal and family, then the church should know. On the other hand, if the Muslim converts to Christianity, there must be a statement signed by the person concerned as proof of religion conversion, so it is hoped that later there will be no regrets that will lead to conflict. In the beginning, there might be some problems, of course, but that is only within the family, and over time the feud ended, because they realized that belief cannot be forced" (Interview with Rev. Rineke Mappalie, 11 March 2019 in Pasalae).

\section{Strengthening Harmony From Outside Influences}

In a multicultural society, religious groups are divided into two, and the first is educated people, a religious community that is always rational in which intuitive and symbolic understandings are put aside so that it is easier to tolerate people of different religions. The second one is ordinary people who prioritize religious symbols and do not use rational analysis so that it is more difficult to tolerate other religions (Casram, 2016:190).
By always prioritizing an attitude of sympathy without any offense, understanding other religions will certainly not cause friction or conflict. It is an unavoidable fact that our society, which is a multicultural society, has the diversity that has been bound in respect to foster mutual trust, including in matters of religion. The condition of heterogeneous religious adherents can create tolerance and cooperation.

Despite the various ethnicities, tribes and religions that inhabit the coast of Pasalae, they live harmoniously in solid kinship bonds, coexist and blend in as a community. The social relations built between them are seamless, both of them live in one bond Torang Samua Basudara.

The question that can arise then is whether disunity or conflict has happened between them so far. The conflict between the two different communities communally in Pasalae has so far been unheard of. However, as an interview with one of the societies stated, in 2010, there was minor chaos when an individual (Christian) ordered a mentally disabled child to put firecrackers in the mosque during the Eid Adha celebration. In the end, the community also beat the person, but the Muslim community helped him survive.

For the people of Pasalae, the important thing that must be maintained in inter-religious relations is the outside influence such as provocation and religious fanaticism from a group. In the Poso conflict, it was suspected that it had slightly affected religious harmony in Pasalae, with the emergence of various provocations from outside to clash the two parties. However, it was resolved through dialogue and because of the Torang Samua Basudara brotherhood.

Ketika terjadi konflik Poso, masyarakat di Desa Pasalae hampir terjadi gesekan, karena adanya provokator yang bersal dari luar. Namun karena rasa persaudaraan dan saling menghargai sehingga masyarakat tidak terpengaruh, kecuali jika ditemukan ada orang yang luar atau orang yang tidak dikenal yang dianggap mencurigakan maka harus diwaspadai. Di samping itu, pemerintah sudah berupaya mengcovernya, namun kewaspadaan adanya provokasi dari luar tetap harus ditingkatkan (wawancara, Hasmiah Paramata, Wawancara, tanggal 10 Maret 2019). 
(When the Poso conflict occurred, there was almost friction in the community in Pasalae Village because of outside provocateurs. However, by the sense of brotherhood and mutual respect, the community is not affected unless it is found that outsiders or unknown persons are considered suspicious, they must be wary of it. In addition, the government has tried to cover it up, but the awareness of external provocations must still be increased (Hasmiah Paramata, Interview, March 10, 2019 in Pasalae).

This is also mentioned by one of the Pastors, the following is an excerpt from the interview:

Sejak tahaun 1998, saya tinggal di Pasaale dan sejak itupula saya belum pernah mendengar adanya konflik yang mengrah pada SARA, ya memang dulu ada upaya untuk itu, tapi hal ini dapat diselesaikan dengan baik. Sebuah komunitas, dikhawtirkan ada orang tertentu yang ingin memecah belah mereka, bisa saja akan terjadi SARA, jika ada orang yang ingin memecah tapi selama ini belum ada yang mengarah pada SARA. Bahkan kemarin waktu pemilihan kades, dari umat Kristian tidak ada yang maju dan mungkin ini penghargaan mereka kepada yang mayoritas (Wawancara, tanggal 17 Maret 2019).

(Since 1998, I have lived in Pasalae, and since then, I have never heard of a conflict that led to SARA; indeed, there were attempts to do so, but this thing can be resolved well. In a community, it is feared that certain people want to divide them, SARA could happen if there are people who attempt to divide, but no one has led to SARA so far. Even yesterday, during the village head election, none of the Christians came forward, which may be their tribute to the majority (Interview, March 17, 2019).

In addition to the influence of external provocations, things that are considered to be able to reduce the values of tolerance that have been built for a long time are when the entry of religious ideas which considered quite fanatical, as stated by $\mathrm{Mr}$. Ramdhan Mapaliey:

Nilai-nilai yang dianggap bergeser dan mengakibatkan penurunan dalam relasi masyarakat, Saya melihat dalam beberapa tahun ini sedikit ada penurunan dalam relasi masyarakat, dulu seingat saya ketika masih kecil, perayaan-perayaan keagamaan IslamKristen sama-sama kita rayakan. Kalau sekarang bukan tidak merayakan lagi, mungkin karena perkembangan zaman, dulu belum ada namanya paham yang sedikit ekstrim, yang fanatic, karena memang beda agama beda larangan. Di Islam itu ada paham yang juga masuk ke Pasalae yang membawa perubahan perilaku keseharian-harian antara dua agama ini, karena benar yang fanatik ini Jamaah Tablig (JT) dilakukan sesuai dengan syariat nabi, baik larangan maupun perbuatannya dilakukan sesuai perintah Rasullah. Salah satunya tidak bisa mengikuti perayaan umat nonmuslim, jadi mungkin ini yang memperngaruhi, bukan berubah tapi sedikit berubah. Misalnya saya ini Islam tetapi keluarga saya hampir semuannya nonmuslim, karena saya muallaf, saya juga masuk di dalam JT tapi saya tidak fanatic seperti itu, apalagi sebagai kepada desa maka tidak boleh membeda-bedakan, apapun agamanya saya wajib support (Wawancara, tanggal 20 Maret 2019).

(Regarding values that are considered to have shifted and resulted in a decline in public relations, I had seen that there had been a slight decline in public relations in recent years, as I remember when I was a child, we celebrated Muslim-Christian religious celebrations together. It does not mean that there is no more celebration now, maybe because of the current development, there was no such thing as a slightly extreme, fanatical understanding, because different religions have different prohibitions. In Islam, there is an understanding that also enters the Pasalae that bring about changes in the daily behavior between these two religions, because it is true that this fanatic Tablighi Jema'ah (JT) is carried out in accordance with the Prophet's Sharia, both prohibitions and actions are carried out according to the orders of the Messenger of Allah. One of them could not follow the celebrations of non-Muslims, so maybe this influenced, will only changing a little. For example, I am Muslim but almost all of my family are non-Muslims, because I am a convert to Islam, I am also a member of the JT but I am not that fanatic, significantly as a villager, I cannot discriminate, regardless of religion, I must be supportive (Interview, Ramdhan Mapaliey, 20 March 2019 in Pasalae).

The presence of the Tablighi Jema'ah (JT) around 2007-2008, was considered capable of changing the religious expression of the Islamic community in Pasalae, which led to a better community's religious practice. However on the other hand, in social relations, there has been a slight shift, especially in the 
religious relationship between the two, where previously, when Christians celebrated holy days, they congratulated each other, but now this practice has begun to fade. However, not all of the Tablighi Jema'ah were doing so, except for the fanatics.

However, it was still tricky for the Tablighi Jema'ah not to build relationships with non-religious groups. This is because they have been bound in kinship ties and cooperation in economic relations between the two, which have existed for quite a long time, even without religious barriers in economic relations. In addition, the call for da'wa delivered by the Tablighi Jema'ah also did not lead to disunity, and it is just that there are some things that Muslims are no longer allowed to do, especially during Christian religious celebrations.

\section{Analyzing the Basis of Religious Harmony in Pasalae}

One of the bases for establishing religious harmony is local wisdom. Local wisdom, as an essential identity for a community or tribe and ethnicity. Huyula as local wisdom found in Gorontalo, is a series of values found in the community and underlies the mutual cooperation system. The selfless work system has become an actual practice that has been carried out for generations by their ancestors as a voluntary coordinated system. Even today, local wisdom Huyula is still social capital in community practice, especially social activities (Wahyuni and Annas, 2014: 2-4).

Gotong royong or Huyula, a social asset that has long existed in the Gorontalo community, served as a bond between them. There were some honest practices of the relationship between them, firstly their willingness to live as neighbors, sharing, inviting and visiting each other, at every celebration. Second, there was no truth claim in each religion. The Pasalae people lived side by side and each run accordingly to the teachings of their religion without blaming other religions. Third, there was the principle of torang samua basudara, as an effort to dismiss differences and avoid conflicts between the two religions. Fourth, kinship (marriage) and fifth, the sea as the economic strength of the Pasalae community which was timeless with the tradition of bagi-bagi ikan as the best practice to strengthen each other.
The fundamental practices built in other communities were different in Pasalae compared to the active tolerance described by Walzer, especially in the last three dimensions. People in Pasalae recognize themselves as different or open to the liyan, but they have lived together and celebrated the differences. They did not just greet others, but it has become a tradition in various aspects of people's lives. It was considered that the built-in tolerance Pasalae, which Diana L. Eck, with the concept of pluralism, is a portrait of life shown in the daily life of the people in Pasalae, active attitudes and behavior through greetings or routines amid diversity.

\section{CLOSING}

Pasalae Village is one of the villages where harmony is created naturally, which is called the best practice of harmony. Different community live side-by-side and socialize with other communities, working together to build dynamic relationships from various aspects of social, economic, religious, and cultural life even today. Meetings in public spaces such as traditional markets and piers are the most strategic places to build social cohesion. Likewise, unified religious relations, caring and mutual respect in religious matters are highly respected, known as baku masuk. Economic relations also become a reinforcement in building harmonious relationships which are considered as tangible evidence in the practice of harmony.

Pasalae village has never been involved in religious conflicts, even when there was a conflict in Poso which was considered to be disrupting the harmony in Pasalae. The principle of Torang Samua Basudara is recorded and ingrained in their lives, thus perpetuating a harmonious life in a variety of ways as an effort to maintain religious harmony in Pasalae. Therefore, the community is expected not to be easily provoked by unclear issues of other religious communities trying to influence other people with fanatical ideas. 


\section{ACKNOWLEDGEMENT}

The authors would like to thank the Makassar Religious Research and Development Agency, for the opport unity to be involved in the 2019 research program. Also, gratitude to Sitti Arafah for the guidance in the writing process and especially to the Al Qalam Journal board member for publishing this article.

\section{REFERENCES}

Akhyar, Z., Matnuh, H., Patimah, S., Patimah, S., \& Study, C. E. (2015). Implementasi toleransi antar umat beragama di desa kolam kanan kecamatan barambai kabupaten barito kuala, 5 .

Ali Fauzi, Ihsan, Pangabean, Rizal, dkk. (n.d.). Mengelola Keragaman. Yogyakarta: yayasan Wakaf Paramadina, Magister Perdamaian dan resolusi Konflik (MPRK) UGM, The Asia Foundation.

Apriyanto, J. (2012). Sejarah Gorontalo Modern dari hegemoni Kolonial ke Provinsi (1 ed.). Yogyakarta: Ombak.

Casram. (2016). Membangun Sikap Tolernasi Beragama dalam Masyarakat Plural Casram. Wawasan: Jurnal Ilmiah Agama dan Sosial Budaya, 1(2), 187-198. https://doi.org/DOI: http://dx.doi.org/10.15575/jw.v1i2.588

Eck. L. Diana. (2006). What Is Pluralism.

Endraswara. Suwardi. (2006). Metode, Teori, Teknik Penelitian Kebudayaan: Ideologi Epistemologi dan Aplikasi (1 ed.). Yogyakarta: Pustaka Widyatama.

Ismail. Hasani. (2008). Berpihak dan Bertindak Intoleran, Intoleransi Masyarakat dan Restriksi Negara dalam Kebebasa Beragama/Berkeyakinan di Indonesia. Jakarta.

Ismail, F. (2017). Islam yang Produktif Titik Tети Visi dab Keumatan dan kebangsaan (1 ed.). Yogyakarta: IRCisod.
Kasniyah. Naniek. (2012). Tahapan Menentukan Informan dalam Penelitian Kualitatif. Yogyakarta: Ombak.

Khotimah. (2016). Interaksi Sosial Masyarakat Islam Kristen di Dusun IV Tarab Mulia Kecamatan Tambang Kabupaten kampar. Kutubkhana, 19(2).

Mamuaya, C. L. dan S. A. (2017). Toleransi Masyarakat islam-Kristen Madura di Desa Sumber jambe Kabupaten Kember. Dimensi, 10(2).

Nazmudin. (2017). Kerukunan dan Toleransi Antar Umat Beragama dalam Membangun Keutuhan Negara Kesatuan Republik Indonesia ( NKRI ). Journal of Government and Civil Society, 1(1), 2339.

https://doi.org/10.6320/FJM.2015.19(5). 12

Spradley, J. . (2007). Metode Etnografi (2 ed.). Yogyakarta: Tiara Wacana.

Syamsurijal, dkk. (2019). Best Prantice Kerukunan Umat Beragama di Kawasan Timur Indonesia (No. 1). Makassar.

Tim Penyusun Dokumen Desa. (2018). Desa Gentuma 2018. Gentuma Raya.

Wahyuni, E. dan A. F. B. (2014). Analisis Esksitensi Kearifan Lokal Desa Bongoime Provinsi Gorontalo. Penyuluhan, IV(1).

Waluyajati, Roro Sri Rejeki dan Farida, L. U. (2018). Pola Interkasi Sosial Keagamaan Antara Penganut Agama Islam dan Kristen Advent. Religioua: Studi Agama dan Lintas Budaya, 2(2).

Walzer, M. (1997). On Tolerantio. London: New Havem and London Yale University Press.

Weldemina Yudit Tiwery. (2018). Larvul ngabal dan ain ni ain sebagai pemersatu kemajemukan di kepulauan kei maluku tenggara. Sosiologi Pedesaan, 6(1), 8 15.

Yewangoe, A. . (2016). Agama dan Kerukunan (4 ed.). Jakarta: Gunung Mulia. 
